\title{
Moderate flies flag for science on Capitol Hill
}

\section{Geoff Brumfiel, Washington}

The hundreds of researchers who trek to Washington each year to talk to the government about science and science funding don't always find Capitol Hill friendly territory. Most in Congress are businesspeople or lawyers by trade - only 3 of the 535 of them are qualified scientists.

But there's one place on Capitol Hill where science can rely on a sympathetic hearing: the Science Committee of the House of Representatives. And since 2001, under the chairmanship of Sherwood Boehlert (Republican, New York), the committee has been enjoying a new lease of life.

Bills that used to be ignored — such as a measure to double funding for the National Science Foundation (NSF) over five years have been quietly moving through Boehlert's committee and then becoming law. The structure of the new Department of Homeland Security actually reflects Boehlert's demand for a top-level research administrator. And when the space shuttle Columbia fell tragically to Earth last month, the science committee took the lead in cajoling NASA to mount a fully impartial investigation.

Boehlert himself is a non-scientist whose moderate views and long-time embrace of environmental conservation place him firmly on the liberal edge of today's Republican Party. But he won the grudging respect of the party leadership for his tenacious defence of environmental regulation, and was allowed to succeed the fiery conservative James Sensenbrenner (Republican, Wisconsin) to take charge of the committee in January 2001.

Two years later, science lobbyists and Capitol Hill veterans credit Boehlert with raising the committee's profile and reputation, hiring dedicated $\mathrm{PhDs}$ as committee staff and making some progress in educating fellow members on current scientific issues. "He's made the science committee more relevant by far than it has been in 20 years," says Frank Cushing, a former member of staff with the House appropriations committee who now lobbies Congress.

Sitting in his high-ceilinged office, a relaxed Boehlert, sporting a tie bearing the colours of his local college basketball team, says that the committee is finally finding its voice. "In the weekly meetings between the House leadership and the committee chairs, the science committee's voice is heard, and often heeded," he says.

He adds that better relations with Senate committees have bolstered his committee's standing. "In the past, the House would do something and the Senate wouldn't respond, or the Senate would do something and the House wouldn't respond. Now we enjoy a very productive partnership."

Boehlert continues to dissent from some

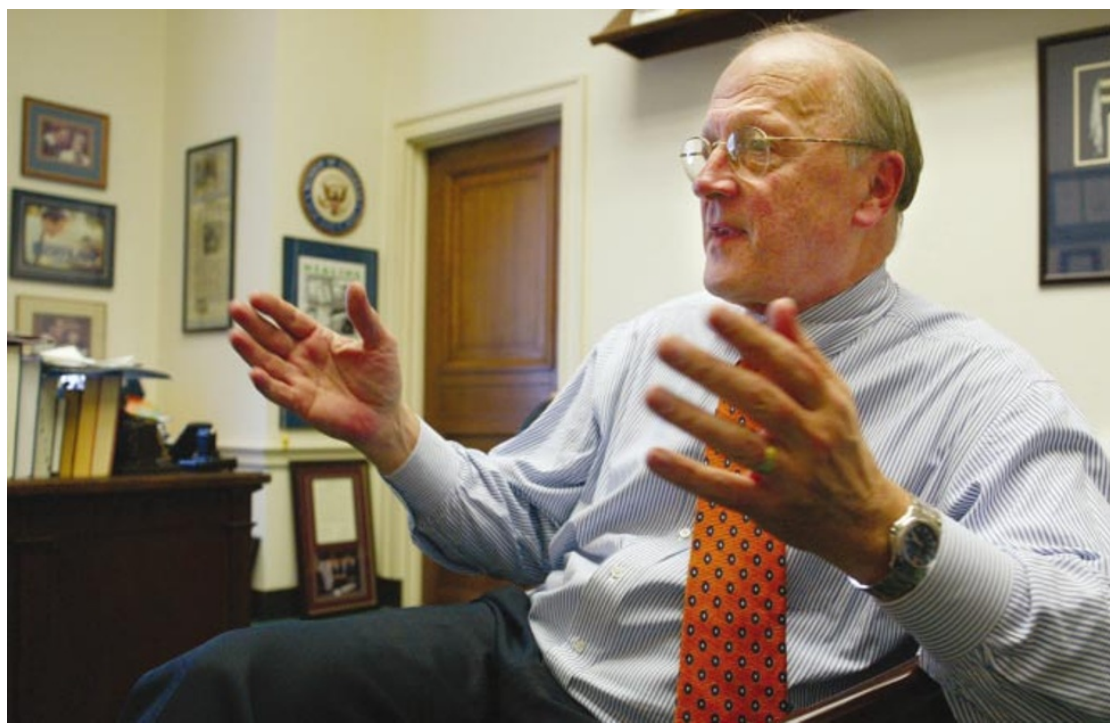

A sympathetic ear: Sherwood Boehlert has won credit for reviving the House science committee.

of the House leadership's views on science - voting last month, for example, against a blanket ban on cloning research that was overwhelmingly passed by the House.

In keeping with the climate in the rest of the city, he has lately been devoting a lot of attention to security issues, including the thorny question of self-censorship in scientific publishing. Boehlert is unhappy with a Bush administration proposal, laid out by presidential science adviser John Marburger last October, that some research be classed as "sensitive but unclassified".

"It's just gibberish to say, 'sensitive but unclassified"," he says. "What does that tell a researcher?" He also doubts that selfcensorship by scientists will work, and says that he supports a simple system in which research is either classified or unclassified. "That's the way I'm leaning — but we're going to have more hearings on it," he says.

\section{The final frontier}

Boehlert's 47-member committee oversees most non-biomedical civilian research programmes in the United States, including those at the NSF, the Department of Energy and the Environmental Protection Agency. But its largest charge is NASA. In the wake of the Columbia accident, the committee has been monitoring the investigation - in partnership with the Senate commerce committee, chaired by John McCain (Republican, Arizona) - while rallying in support of the embattled manned spaceflight programme and its centrepiece, the International Space Station.

Boehlert says he is worried about the ability of the pared-back space station to do research. "Most of us were operating under the assumption that it took two-and-a-half people to operate the station. Now NASA says it can operate with two staff and still get some research done. Is it enough research to justify the cost? Not by a long shot." Yet he remains optimistic that the station, and manned flight in general, will prove beneficial in the long run. "I've got to be very pragmatic as I look at manned space flight in the future, and I'm going to have to ask, 'is it worth it?' My gut reaction right now is yes." Boehlert is planning further hearings to look at the future of NASA's manned space-flight programme.

A committee hearing this week will investigate the complaints of foreign scientists who are being delayed from entering the United States by new immigration laws. "What we desperately need in the twenty-first century is an increased emphasis on international research collaboration," Boehlert says. "It's short-sighted and counterproductive to close our borders."

He adds that much of his committee's time in the coming year will be devoted to keeping a healthy budget for science as lawmakers move to cut spending to pay for homeland security and the war with Iraq.

But the five-year NSF budget plan passed by Congress last year is only a recommendation, and Boehlert must still get Congress's appropriations committees to implement it. He says he plans to do this "by convincing them to the best of my ability that this investment is going to pay handsome dividends".

In the meantime, Boehlert's persuasiveness and middle-of-the-road manner continue to accrue respect for his committee in Congress. A glowing profile of the committee that appeared last week in The Hill, Capitol Hill's local newspaper, echoed the message he wants to project: "Quiet committee rising," the headline said. 